\title{
Millenial Generation Opportunities As The Economic Driver Through The Creative Economy
}

\author{
Yusri \\ \{yusri020286@gmail.com\}
}

Universitas Sari Mulia

\begin{abstract}
Creative Economy as one of the driver of the national economy plays an important role. The support of all parties in encouraging the creative economy to be developed is very much needed in the midst of changes and developments of the industrial revolution. The purpose of this article is to be used as an additional literature review for research in the management environment, especially in the creative economy. The method used was library research or literature review. The results was explained that the creative economy is currently where all access is very easy to contribute as well as great opportunities for millennials in driving the economy in Indonesia that is increasingly productive and creative in helping to improve the community economy towards the Asean Economic Community. Creative Economy in becoming young entrepreneurs are creative, independent and productive.

Keywords: Millennial generation opportunities, creative economy
\end{abstract}

\section{Introduction}

In Indonesia, entering the second millennium, the Government enacted Law No. 22 of 1999 concerning Regional Government which marks the beginning of the era of decentralization aimed at realizing good governance, public service providers and increasing regional competitiveness towards a prosperous society. This creates community familiarity with the creative economy which is realized through the creative home industry that sells creative ideas to generate income. The experts call it the term "creative economy" which is a new "economic talent" that changes people's lives through creative ideas / ideas, which produce economic value-added products that can make life more prosperous. [5]. In the era of free trade, the challenge is not only to prepare human resources (HR) who are ready to work, but also must be able to prepare and open new jobs. The reality that occurs in Indonesia today, presents a paradigm that the Indonesian people are educated to become job seekers. With unstable economic conditions, security and safety at work are the main objectives, and the establishment is obtained after being an employee who gets a fixed monthly salary. This ends with the problem of unemployment, which is a structural and chronic disease that afflicts all developing countries, because those who are looking for work every year continue to grow, while the available jobs are insufficient. As a result, every year the number of unemployed continues to increase. This is evidenced by the hectic job market which is crammed with job seekers. The development of Indonesia's Creative Economy is a form of optimism and overflowing of aspirations to support realizing Indonesia's vision of becoming a developed country. Inside there are thoughts, ideals, imagination, and dreams to become a society with high quality of life, prosperity, and creativity. The creative economy makes human resources (HR) as the main capital in a development that starts with ideas, ideas and thoughts. In the future, it is expected that this human resources can make low-value goods into high-value 
goods and sell power. A profession that requires a person to have high creativity is an entrepreneur. So the development of this creative economy indirectly directs and tries to create reliable entrepreneurs in various fields. The power of creativity must be based on advanced ways of thinking, full of new ideas that are different from existing ones [2]. The development of science and technology has been able to change the outlook, mindset, and patterns of human life and is able to encourage the creation of inventions that can inhibit the scarcity of goods and services. Through innovation, research, and development that is continuously created what products and services are desired and needed by consumers. The impact is changing global economic life patterns in various fields, such as production patterns, distribution patterns, and consumption patterns. and lead to patterns of need and consumption patterns that are stimulated by the creation of new products [5]. Millennials are those who are young people born between 1980s and 2000s. Millennials are born where the modern world and sophisticated technology are publicly introduced. Millennials come of age in a time when the entertainment industry is beginning to be affected by the internet and mobile devices [6]. The role of the creative economy in the national economy as well as Indonesia's characteristics which are well-known for the socio-cultural diversity that is spread throughout the archipelago can certainly be a source of inspiration in developing creative industries [5]. The entry of the era of the industrial revolution 4.0 became an important moment for Indonesia in spurring the competence of human resources (HR). For this reason, efforts are needed to develop educational transformation that is in line with the needs of the world of work today. Industry 4.0 encourages the government to empower human talents. Millennial generation plays an important role in implementing industry 4.0. Moreover, Indonesia will enjoy a demographic bonus period until 2030. This means that as many as 130 million people of productive age can take up new opportunities to develop business in the digital era [7]. By observing statistical data infographics and the results of the 2016 Creative Economy survey, it is seen that the Creative Economy is able to contribute significantly to national economic growth. In 2015, this sector contributed 852 trillion rupiah to the national GDP (7.38\%), absorbed 15.9 million workers (13.90\%), and export value of US \$ 19.4 billion $(12.88 \%)$. The data also shows a significant increase in the contribution of the Creative Economy to the national economy from $2010-2015$ at $10.14 \%$ per year. This proves that the Creative Economy has the potential to develop in the future [8]. 

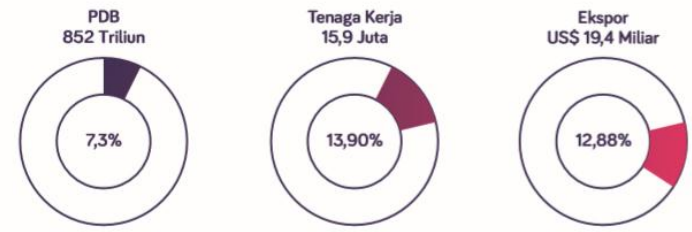

Fig. 1. Creative Economy has the potential to develop in the future

\section{Methodology}

The research method which is based on the literature study in the literature review of several related research journals has been formed, the question is whether what is actually meant by the creative economy and how the role of the Creative Economy and Opportunities for the millennial generation in economic drivers . The type of data used is secondary data. The data collection method is a literature study from several existing journals. The method to be used for this study is the study of literature. The data obtained is compiled, analyzed, and concluded so as to get a conclusion. With 8 articles or journals reviewed.

\section{Discussion}

\subsection{What is a Creative Economy}

In a literature review of research journal on the development of the creative economy in the fashion through marketing mix, it is said that the creative economy is the development of economic activities based on the creativity, skills and talents of individuals to create creative and creative power of individuals with economic value [3]. While in the literature study from research on the development of a creative economy based on cultural tourism, it was said that the creative economy is an economic activity by prioritizing creative thinking, thinking something new [4]. Likewise in literature study research on the effect of the application of the creative economy on the creativity of adolescents in the city of Lhokseumawe said that the creative economy is an evolving concept and is based on assets that have the potential to produce economic growth and development [1]. From the outline of the three literary literatures, it can be said that what is meant by creative economy is an industry based on creativity that is always evolving in creating something new with the ability to think to create a creative business. This is one of the drivers of the national economy which plays an important role. With the support of all parties in encouraging and developing it, it is certainly very much needed amidst the changes and developments of the current industrial revolution. 


\subsection{What is the role of the Creative Economy and Opportunities for the millennial generation in the economic driving force 4}

As we know that increasing population will certainly encourage economic growth as well, which will indirectly expand markets and specialization in the economy. Thus of course economic activity will increase as well. From the reality in the field this is also the development of innovation and the creation of new businesses based on thought and creativity are often found in line with current technological advances. And this is the role of the creative economy is very large in helping to move and improve the economy, especially those in the regions. The role of the creative economy is directly involved in contributing to accelerate the process of economic development, enhance the level of work productivity and encouraging technological development.

There are several things that can be used as opportunities for the current millennial generation in creating creative businesses with various aspects of choice such as [1]:

1) Advertising: Covers the process of creation, operation and distribution of the resulting advertising, for example market research, advertising communication planning, outdoor advertising media, advertising material production, promotion and public relations campaigns.

2) Architecture: For example park architecture, urban planning, construction cost planning, conservation of heritage buildings, construction supervision, urban planning, consulting of engineering and engineering activities such as civil buildings and mechanical and electrical engineering.

3) Art Goods Market: trading of original, unique and rare goods and having a high artistic aesthetic value through auctions, galleries, shops, supermarkets and the internet including music items, printing, handicraft, automobile and film.

4) Crafts: includes handicraft items made of: precious stones, natural or artificial fibers, leather, rattan, bamboo, wood, metal, wood, glass, porcelain, marble, clay and lime.

5) Design: includes graphic design creations, interior design, product design, industrial design, corporate identity consulting and marketing research services as well as packaging production and packaging services.

6) Fashion: includes fashion designs, footwear designs and other fashion accessories designs, fashion product line consultations, and fashion product distribution.

7) Video, Film and Photography: includes video production and photography services, as well as distribution of video recordings, films and photographic results. This includes writing scripts, dubbing films, cinematography, soap operas and film exhibitions

8) Games: the creation, production, and distribution of computer and video games that are entertainment, agility and education. The interactive game sub-sector is not dominated by mere entertainment but also as a learning or educational tool.

9) Music: includes the creation or composition, musical performance, reproduction and distribution of sound recordings.

10) Performing Arts: includes efforts to develop content, show production, ballet performances, traditional dances, treater music, opera, including ethnic music, design and manufacture of performance clothing, stage and lighting. 
11) Publishing and printing: includes writing content and publishing books, journals, newspapers, magazines, tabloids and digital content and news agency activities.

12) Computers: includes creative activities related to information technology development including computer services, software development, system integration, system design and analysis, software architecture design, software infrastructure design and hardware and portal design

13) Television and Radio: includes creative activities related to the business of creating, producing and packaging, broadcasting and transmitting television and radio

14) Research and Development: includes innovative businesses that offer the discovery of science and technology and the application of knowledge and knowledge for product improvement and the creation of new products, new processes, new materials, new tools, new methods and technologies that can meet market needs.

\section{Conclusions}

From several studies that have been traced based on existing literature studies, the creative economy salah satu sektor yang diharapkan mampu menjadi kekuatan baru ekonomi nasional di masa mendatang, seiring dengan kondisi sumber daya alam yang semakin terdegradasi setiap tahunnya. The driving forces of creative business today are the youngest people of the millennial generation with extraordinary power and thinking abilities. With the economic opportunities that exist both the natural resource economy and the existing human resource economy this is certainly a great opportunity for millennials to help develop the creative economy and drive the economy in Indonesia.

\section{Recommendations}

Many potentials that exist in the regions that can be used as creative industries that can be developed again, carried out excavations in the creation of new products with the potential of various local wealth sectors of a region and this will hopefully not only help improve the economy of a region and country but also able to improve the community economy towards the Asean Economic Community in the hands of creative, independent and productive young entrepreneurs.

\section{References}

[1] Alvien Septian Haerisma, "Creative Economy Development in Fashion through Marketing Mix", Al-Amwal, Volume 10, No. 1 of 2018 DOI: 10.24235 / amwal.v10i1.2831 (2018)

[2] Zul Asfi Arroyhan Daulay, "Strategi pengembangan ekonomi kreatif dengan metode Triple Helix (Studi pada UMKM Kreatif di Kota Medan). Tansig, Vol 1, No.2, Juli-Desember(2018)

[3] Siti Nur Azizah dan Muhfiatun, "Pengembangan ekonomi kreatif berbasis kearifan lokal Pandans handicraft dalam menghadapi pasar modern perspektif ekonomi syariah (study case di Pandans Nusa Sambisari Yogyakarta)", APLIKASIA: Jurnal Aplikasi Ilmu-Ilmu Agama Volume 17, Nomor 2, Page: 63-78. ISSN 1411-8777/EISSN 2598-2176 (2017) 
[4] Sumar'in, Andiono and Yuliansyah, "Development of a Creative Economy Based on Cultural Tourism: A Case Study of Weaving Craftsmen in Sambas District", Journal of Business Economics and Entrepreneurship 2017, Vol. 6, No. 1, 1-17 (2017)

[5] Rusydi, Noviana, "The Effect of the Application of Creative Economy on Youth Creativity in Lhokseumawe City", JOURNAL VISIONER \& STRATEGIC Volume 5, Number 1, March 2016 ISSN: 2338-2864 p. 51-59 (2016)

[6] https://id.wikipedia.org/wiki/Milenial

[7] https://kemenperin.go.id/artikel/19978/Generasi-Milenial-Kompeten-di-Sektor-Kreatif-DigitalSambut-Industri-4.0-

[8] https//www.bekraf.go.id $>$ data-statistik-dan-hasil-survei-ekonomi-kreatif 